DOI: $10.1590 / 1089-6891 v 20 \mathrm{e}-52164$

MEDICINA VETERINÁRIA

\title{
EFFECTIVENESS OF TOBRAMYCIN AND CIPROFLOXACIN AGAINST BACTERIAL ISOLATES IN CANINE OTITIS EXTERNA IN UBERABA, MINAS GERAIS
}

\section{EFICACIA DE TOBRAMICINA E CIPROFLOXACINA CONTRA ISOLADOS BACTERIANOS DE OTITE EXTERNA CANINA EM UBERABA, MINAS GERAIS}

Jandra Pacheco dos Santos ${ }^{1 *}$ ORCID- http://orcid.org/0000-0001-6922-2662

Álvaro Ferreira Júnior ${ }^{2}$ ORCID- http://orcid.org/0000-0001-7648-2323

Carla Cunha Locce ${ }^{3}$ ORCID- http://orcid.org/0000-0002-6141-1570

Silvia Cassimiro Brasão ${ }^{1}$ ORCID- http://orcid.org/0000-0003-3915-734X

Eustáquio Resende Bittar ${ }^{3}$ ORCID- http://orcid.org/0000-0002-7176-9920

Joely Ferreira Figueiredo Bittar ${ }^{3}$ ORCID- http://orcid.org/0000-0002-1813-9006

1 Universidade Federal de Uberlândia, Uberlândia, MG, Brazil.

${ }^{2}$ Universidade Federal de Goiás, Goiânia, GO, Brazil

3Universidade de Uberaba, Uberaba, MG, Brazil

*Correspondent author - jandra.santos@yahoo.com.br

\begin{abstract}
Canine otitis externa is a common and recurrent disease in domestic dogs. Although not being life threatening, it can result in the overuse of antibiotics, increased bacterial resistance and reduction of options for treatment. This study aimed to determine: the principal characteristics (age, race, and gender) of dogs affected by otitis externa; the most frequently bacteria identified as being associated with it and their antimicrobial resistance profiles. A total of 221 bacterial isolates were identified by morphological staining and biochemical processes and tested against eleven antibiotics. Among the 148 dogs diagnosed with otitis externa, 51.4\% (76/148) were males and 48.6\% (72/148) females. The cases were detected mainly in dogs with age above 7 years $(54.7 \% ; 81 / 148$. Among the races examined, poodles were the most numerous $(14.84 \% ; 22 / 148)$. The most common bacteria found were: coagulase-negative Staphylococcus (StCN), 33.9\% (75/221); coagulase-positive Staphylococcus (StCP), 19\% (42/221); Proteus spp., 17.2\% (38/221) and Pseudomonas aeruginosa, 9.5\% (21/221). Simultaneous resistance to more than three classes of antimicrobials were most frequently detected in P. aeruginosa $(61.9 \% ; 13 / 21)$ and Proteus spp $(39.47 \% ; 15 / 38)$. According to data obtained from this study, two veterinary medications found to be most effective for topical treatment were tobramycin and ciprofloxacin.
\end{abstract}

Keywords: antimicrobial, bacteria infection, dogs, ear, resistance

\section{Resumo}

A otite externa canina é uma doença comum e recorrente em cães domésticos. Embora não seja uma ameaça à vida, pode resultar no uso excessivo de antibióticos, aumento da resistência bacteriana e redução das opções de tratamento. Este estudo teve como objetivo determinar: as principais características (idade, raça e gênero) de cães afetados por otite externa; as bactérias mais frequentemente identificadas como associadas a enfermidade e seus perfis de resistência. Um total de 221 isolados bacterianos foram identificados por características morfo-tintoriais e testes bioquímicos, e posteriormente testados contra onze antibióticos. Entre os 148 cães com diagnóstico de otite externa, 
51,4\% (76/148) eram machos e 48,6\% (72/148) fêmeas. Os casos foram detectados principalmente em cães com idade acima de 7 anos $(54,7 \% ; 81 / 148)$. Entre as raças examinadas, poodles foram os mais acometidos $(14,84 \% ; 22 / 148)$. As bactérias mais encontradas foram: Staphylococcus coagulasenegativo. (StCN), 33,9\% (75/221), Staphylococcus coagulase-positiva (StCP), 19\% (42/221), Proteus spp., 17,2\% (38/221) e Pseudomonas aeruginosa, 9,5\% (21/221) Resistência simultânea a mais de três classes de antimicrobianos foi mais frequentemente detectada em P. aeruginosa $(61,9 \% ; 13 / 21)$ e Proteus spp $(39,47 \%$; 15/38). Segundo os dados obtidos neste estudo, os antibióticos com maior capacidade de inibição do crescimento bacteriano in vitro foram tobramicina e ciprofloxacina.

Palavras-chave: antimicrobiano, infecção bacteriana, cães, orelhas, resistência

Received on: April, 13th, 2018.

Accepted on: June 5th, 2019.

\section{Introduction}

Otitis externa is a common problem of dogs taken to veterinary centers ${ }^{(1)}$ for treatment. The result is often related to excessive use of antibiotics. The clinical signs include ear inflammation and may be associated with a more complex disease process including a combination of primary causes: atopic dermatitis, foreign bodies, or simply conformational abnormalities or excess hair in the ear canal and perpetuated by bacteria and fungi( ${ }^{(2)}$.

Microbiology laboratories should periodically and systematically conduct etiological identification and antimicrobial susceptibility testing to help ensure appropriate treatment and monitor the epidemiological profiles of isolated bacteria ${ }^{(3)}$. Positive coagulase Staphylococcus (StCP) and Pseudomonas aeruginosa are bacteria often isolated in canine otitis externa ${ }^{(4)}$.

The treatment of this disease is based on the use of antibiotics, including aminoglycosides, quinolones, amoxicillin/clavulanate and cephalosporins, nevertheless, the incorrect and/or prolonged use of these drugs can result in bacterial resistance to antibiotics ${ }^{(5)}$. Otitis treatment using erythromycin, penicillin, neomycin or sulfa drugs ${ }^{(6,7)}$, in the face of Gram positive and Gram negative bacteria, has been described as having low efficiency, while the drugs, ciprofloxacin and tobramycin has shown higher ability to inhibit the bacterial growth ${ }^{(4)}$.

This study aimed to determine the main characteristics (race, age and gender) of dogs affected with otitis externa, characterize frequently isolated bacteria and describe the antimicrobial resistance profiles of diagnosed bacterial isolates.

\section{Material and methods}

An observational and descriptive study was conducted, using clinical and microbiological data on dogs attended in the Uberaba Veterinary Hospital, in Uberaba, Minas Gerais, Brazil, between 2009 and 2013. The criteria for inclusion in the study were: (i) clinical diagnosis of otitis externa; (ii) bacterial identification; (iii) antimicrobial susceptibility testing and (iv) at least 15 days without antibiotics before the collection of material, since the reliability of the cultures obtained can be reduced by the use of antimicrobial agents. The clinical signs of otitis externa considered in this study were: (i) the 
presence of secretion in the ear; (ii) unpleasant odor; (iii) auditory canal hyperemia and (iv) pain upon palpation. Bilateral samples were collected separately from 93 dogs, while 55 animals had only one sample collected. The total was, thus, 148 dogs and 241 auditory canal samples.

Samples of ear discharge were collected using sterile swabs after cleaning the excess ear secretion with $70 \%$ alcohol. Samples of bilateral otitis were collected and cultured separately. The time between collection and the cultivation was less than 30 minutes. The samples were cultivated in blood agar (Oxoid ${ }^{\circledR}$ ) and MacConkey (Difco ${ }^{\circledR}$ ), by aerobic incubation at $37^{\circ} \mathrm{C}$ for 24 to 72 hours. The bacterial colonies were identified by their morphological, staining and biochemical characteristics ${ }^{(8)}$.

The Antimicrobial Susceptibility Testing (TSA) was conducted using the Kirby-Bauer disk diffusion method on Mueller Hinton Agar (Difco ${ }^{\circledR}$ ), and interpretation of the results performed according to the Clinical and Laboratory Standards Institute ${ }^{(9)}$. An intermediate pattern of susceptibility was classified as resistant. The following antibiotics were tested: amikacin $(30 \mu \mathrm{g})$; ampicillin $(10 \mathrm{mg})$; azithromycin $(15 \mu \mathrm{g})$; amoxycillin/clavulanic acid $(30 \mu \mathrm{g})$; cephalexin $(30 \mu \mathrm{g})$; ceftiofur $(30 \mu \mathrm{g})$; ciprofloxacin $(5 \mu \mathrm{g})$; enrofloxacin $(5 \mu \mathrm{g})$, gentamicin $(10 \mathrm{mg})$; neomycin $(30 \mu \mathrm{g})$ and tobramycin $(10 \mathrm{mg})$. Strains of Staphylococcus aureus (ATCC: 25923); Escherichia coli (ATCC: 25922) and Pseudomonas aeruginosa (ATCC: 27853) were used as controls. Multi drug resistance was defined as resistance of the bacterial isolate on a combined basis, to three or more distinct classes of antibiotics ${ }^{(7)}$.

\section{Results}

Altogether, there were identified 148 dogs showing clinical signs of otitis externa during the period from 2009 to 2013. Among these animals 51.4\% (76/148) were males and 48.6\% (72/148) were female. The majority of the dogs were above seven years old $(54.7 \% ; 81 / 148)$. There was a predominance of purebred dogs $(68.8 \%$; 102/148) and fewer mongrel dogs $(31.2 \%$; 46/148). Poodles $14.84 \%(22 / 148)$ followed by Cocker Spaniels 12.15\% (18/148) and Shih Tzu 7.4\% (11/148) were the most affected (Figure 1).

The microorganisms growth was verified in $87.1 \%(210 / 241)$ of the samples, while $12.9 \%(31 / 241)$ did not develop any colonies. Among the plates that showed growth, 73.8\% (155/210) had only one type of colony of bacteria and $15.7 \%(33 / 210)$ had two visually different types. The growth of yeasts, probably Malassezia spp., occurred in 10.5\% (22/210) of the cultures with agar blood, as the only culture.

There was a predominance of Gram-positive bacteria $(65.6 \% ; 145 / 221)$, with coagulase negative Staphylococcus (StCN) and coagulase positive Staphylococcus $(\mathrm{StCP})$ as the most frequent. Proteus spp. and Pseudomonas aeruginosa were the prevailing Gram negative bacteria. Other bacteria with lower occurrence were also isolated (Table 1). 


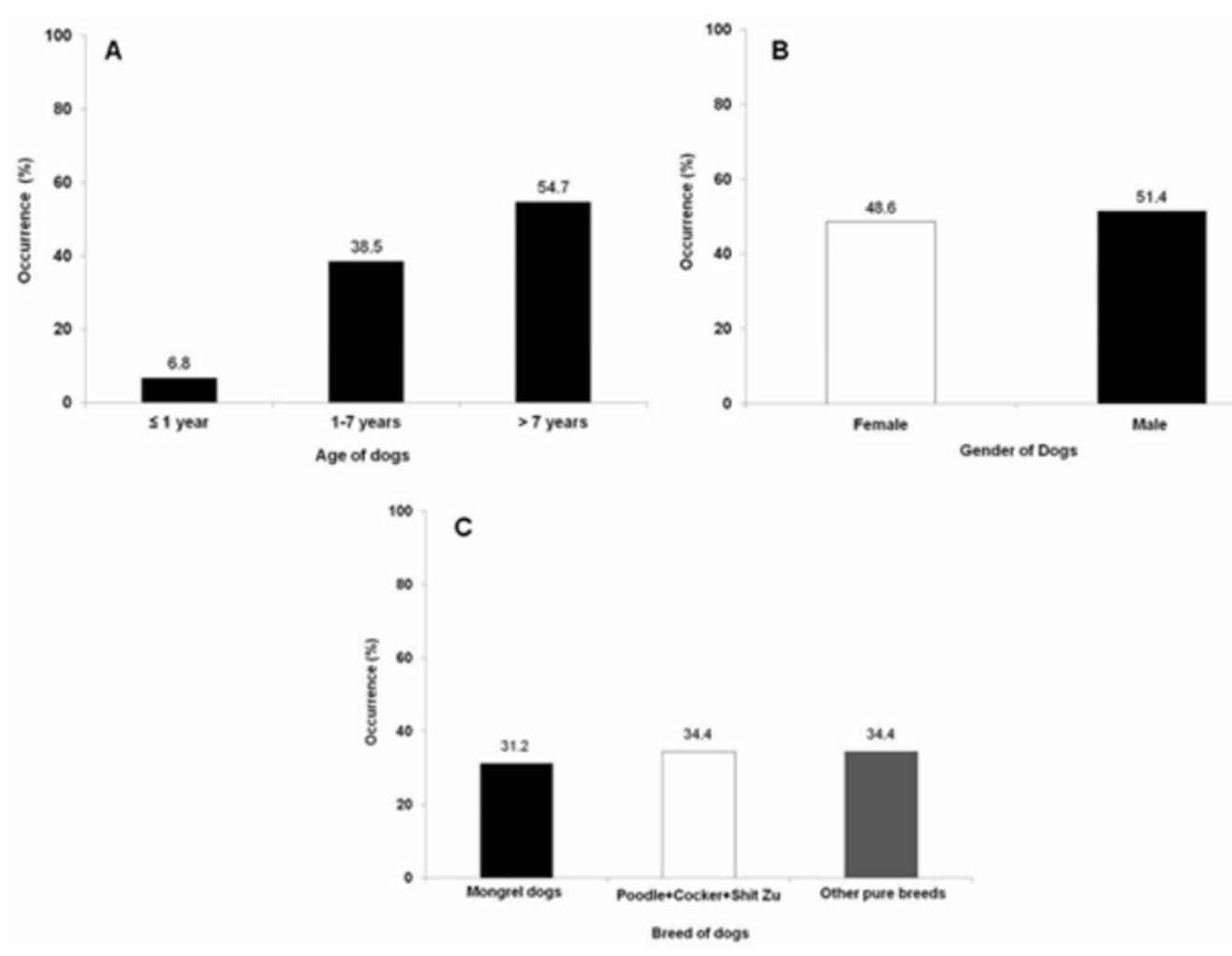

Figure 1 The characterization of 148 dogs diagnosed with otitis externa according to:

(A) age; (B) sex and (C) breed in Uberaba, Minas Gerais, Brazil.

Table 1 Identification of 221 bacteria samples taken from the ear of dogs with otitis externa attended in Uberaba, Minas Gerais, Brazil.

\begin{tabular}{lc}
\hline Genera & $\%(\boldsymbol{n})$ \\
\hline Gram Positive Bacteria & $51.7(75 / 145)$ \\
StCN & $29.0(42 / 145)$ \\
StCP & $7.6(11 / 145)$ \\
Corynebacterium spp. & $6.9(10 / 145)$ \\
Streptococcus spp. & $4.8(7 / 145)$ \\
Enterococcus spp. & \\
Gram Negative Bacteria & $50.0(38 / 76)$ \\
Proteus spp. & $27.6(21 / 76)$ \\
Pseudomonas aeruginosa & $10,5(8 / 76)$ \\
Enterobacter spp. & $6,6(5 / 76)$ \\
Escherichia coli & $5,3(4 / 76)$ \\
Klebsiella spp. & \\
\hline
\end{tabular}

$\mathrm{StCN}$ (coagulase negative Staphylococcus); StCP (coagulase positive Staphylococcus) 
StCN and StCP colonies showed lower resistance levels to amicacina, ceftiofur and the association of amoxicilina/clavulanate (Table 2). Proteus spp. and P. aeruginosa demonstrated higher percentages of colonies resistant to neomycin, azithromycin and cephalexin. The percentage of colonies resistant to gentamicin was similar among the four genera of bacteria (Table 2).

Table 2 Resistance in vitro of the most common bacterial isolates found in ears of dogs with otitis externa attended in Uberaba, Minas Gerais, Brazil.

\begin{tabular}{|c|c|c|c|c|}
\hline \multirow[b]{2}{*}{ Antibiotics } & \multicolumn{4}{|c|}{ Frequence of resistant $(\%)$} \\
\hline & Proteus spp. & $\begin{array}{l}\text { Pseudomonas } \\
\text { aeruginosa }\end{array}$ & $\mathrm{StCN}$ & $\mathrm{StCP}$ \\
\hline \multicolumn{5}{|l|}{ Aminoglycosides } \\
\hline Amikacin & 16 & 19 & 3 & 0 \\
\hline Gentamicin & 29 & 29 & 35 & 32 \\
\hline Neomycin & 69 & 92 & 26 & 25 \\
\hline Tobramycin & 33 & 0 & 29 & 0 \\
\hline \multicolumn{5}{|l|}{ Cephalosporins } \\
\hline Cephalexin & 81 & 82 & 16 & 10 \\
\hline Ceftiofur & 28 & 79 & 9 & 6 \\
\hline \multicolumn{5}{|l|}{ Macrolides } \\
\hline Azithromycin & 92 & 58 & 39 & 21 \\
\hline \multicolumn{5}{|l|}{ Penicillins } \\
\hline $\begin{array}{l}\text { Amoxycillin/clavulanic } \\
\text { acid }\end{array}$ & 50 & 94 & 3 & 0 \\
\hline Ampicillin & 53 & 100 & 46 & 68 \\
\hline \multicolumn{5}{|l|}{ Quinolones } \\
\hline Ciprofloxacin & 8 & 0 & 23 & 5 \\
\hline Enrofloxacin & 34 & 80 & 36 & 40 \\
\hline
\end{tabular}

Among $P$. aeruginosa colonies, $61.9 \%$ showed simultaneous resistance to more than three classes of antimicrobials, while Proteus spp. revealed $39.47 \%$ of its colonies with the same profile (Table 3). 
Table 3 Resistance in vitro to three or more classes of antibiotics, by the bacterial isolates that most occur in ears of dogs with otitis externa attended in Uberaba, Minas Gerais, Brazil.

\begin{tabular}{ccccc}
\hline Bacteria & $\begin{array}{c}\text { Proteus spp. } \\
\%(n)\end{array}$ & $\begin{array}{c}\text { Pseudomonas } \\
\text { aeruginosa } \\
\%(n)\end{array}$ & $\begin{array}{c}\text { StCN } \\
\%(n)\end{array}$ & $\begin{array}{c}\text { StCP } \\
\%(n)\end{array}$ \\
\hline $\begin{array}{c}\text { Multi } \\
\text { resistence }\end{array}$ & $39.47(15 / 38)$ & $61.9(13 / 21)$ & $33.33(25 / 75)$ & $16.66(7 / 42)$ \\
\hline StCN (coagulase negative Staphylococcus); StCP (coagulase positive Staphylococcus)
\end{tabular}

\section{Discussion}

The characterization of the canine population studied revealed agreement with other authors, in respect to the most common breeds of dogs with otitis externa $(\mathrm{OE})^{(4,11)}$. The sex of the animals was not decisive for the occurrence of this condition, as reported in other studies ${ }^{(4,10)}$. Dog breeds with the ear canal lined with hair and excessive production of ear wax and/or in high humidity locations, showed predisposition to some inflammation of the externa ear $^{(2,11)}$.

In the present study, there was a higher number of inflammatory processes in the ears of dogs over seven years old, suggesting that age may influence the occurrence of OE. This apparent predisposition may be associated with endocrine diseases or immune mediated disorders in older $\operatorname{dogs}^{(2,11)}$.

The absence of bacterial growth, observed in $12.9 \%$ of the analyses, does not imply the absence of inflammation in the auditive canal ${ }^{(12)}$. Not all canine OE processes are caused by bacteria. Other microorganisms may be involved such as mites and yeast or filamentous fungi ${ }^{(2)}$. Fungi require different culture conditions than those for bacteria ${ }^{(8)}$. The growth of yeasts, probably Malassezia spp., was observed in $10.5 \%$ of the cultures in blood agar.

Lesions in the epithelium of the ear canal can create a suitable environment for excessive multiplication of microbes, resident or transient, leading to inflammation ${ }^{(13)}$. In canine OE, the identification of Gram-positive bacteria is more often found than Gram-negative ${ }^{(13)}$, with bacteria of the genus Staphylococcus spp. the most commonly isolated ${ }^{(2,4,12,14)}$. Positive coagulase Staphylococcus (StCP) is the most frequent inflammation of the canine ear canal ${ }^{(13,14)}$. However, in this study coagulase negative Staphylococcus ( $\mathrm{StCN}$ ) was the most more frequently found, corroborating other studies ${ }^{(4,15)}$.

In the public health context the biology and epidemiology of coagulase negative Staphylococcus (StCN) must be accompanied systematically ${ }^{(16,17)}$. The transmission of these bacteria among animals and humans has been described ${ }^{(5,18)}$. StCN has the potential to produce severe infection in immune suppressed individuals, including humans ${ }^{(19,20)}$ and transfer genes for multi resistance genes to other bacteria $^{(21)}$. In the present study $33.3 \%$ of the StCN isolates were resistant to three or more classes of antibiotics.

P. aeruginosa and Proteus spp. are among the most common enterobacteria isolated from canine ear 
canal infections ${ }^{(4,22)}$. The elevated number of observations of these microorganisms among dogs with $\mathrm{OE}$, can be understood as a complication of the inflammation ${ }^{(13,14)}$.

The aminoglycosides are presently considered the drugs of choice for the treatment of otitis because of their efficiency ${ }^{(23)}$. Tobramycin also demonstrated effectiveness in inhibiting colonies of StCP and P. aeruginosa colonies ${ }^{(4)}$. Gentamicin and neomycin, routinely used in antibiotic formulations for topical treatment of ear diseases ${ }^{(24)}$, was found to be of low efficiency. This finding reinforces the need for testing of sensibility ${ }^{(7)}$. In spite of the requirement to test its high efficacy, amikacin is not available in veterinary medicines but may be used in specific cases ${ }^{(25)}$. Perhaps the great variation observed in the effectiveness of the aminoglycosides tested was due to the lack of criteria for choosing these antibiotics.

In terms of the quinolones, although $P$. aeruginosa has been found to be resistant to enrofloxacin, as described in other works ${ }^{(13,26,27)}$, the same phenomenon was not observed for ciprofloxacin in this study. Excessive use of quinolones in the antibiotic therapy procedures with dogs may explain the resistance to enrofloxacin and perhaps in the future, ciprofloxacin ${ }^{(26,27)}$.

Other antibiotics, such as penicillins, cephalosporins, and macrolides have formulations for systemic treatment of various diseases in animals, among them, cases of otitis. This route of administration is usually restricted to cases in which the otitis externa is severe, there is the presence of a medium level of otitis infection and/or the owner is unable to carry out the topical treatment ${ }^{(28)}$.

In this study, StCN and StCP were susceptible to amoxicillin/clavulanate, probably due to the presence of the inhibitor of beta-lactamase (clavulanate), which may have enhanced the bactericidal effect of this antibiotic $^{(29)}$. Gram-negative bacteria were resistant to the first-generation cephalosporins, possibly as a result of the narrower spectrum of action of these antibiotics ${ }^{(23)}$ The multi resistance intrinsic of the Pseudomonas aeruginos ${ }^{(8,30)}$ and the formation of biofilm ${ }^{(31,32)}$ are factors that justify the few options for treatment. Azithromycin has shown variable efficiency against StCP, StCN, Proteus spp. and P. aeruginosa, however, there are reports of bacterial resistance to this antibiotic ${ }^{(33)}$. Bacteria resistance is its ability to evade from the bactericidal or bacteriostatic mechanisms of a particular antibiotic, which reflects their structural or functional characteristics ${ }^{(34)}$. In this context, the identification of antibiotic bacteria resistance is relevant for an efficient antibiotic choice and successful treatment ${ }^{(35)}$.

The results of this research show that breed and age are determining factors in the diagnosis of OE, regardless of the sex of the dogs. It was found that Gram-positive bacteria predominate in cases of canine OE, StCN being the microorganism most frequently isolated. Topical medications are most commonly used for otitis. In this context, tobramycin and ciprofloxacin are the most effective antibiotics, in accordance with the data in vitro obtained in this study. The data also revealed a large variation in the sensitivity to antibiotics and elevated resistance to the medications commonly used in canine therapy for otitis externa.

\section{References}

1. O’Neill DG, Church DB, McGreevy PD, Thomson PC, Brodbelt DC. Prevalence of disorders recorded in dogs attending primary-care veterinary practices in England. PLoS One 2014; 9: 1-16.

2. Rosser JR, EJ. Causes of otitis externa. Vet Clin North Am Small Anim Pract 2004; 34:459-468.

3. Morosini MI, Cercenado E, Ardanuy C, Torres C. Detección fenotípica de mecanismos de resistencia em microorganismos. Enferm Infecc Microbiol Clin 2012; 30:325-332. 
4. Oliveira LC, Medeiros CMO, Silva ING, Monteiro, AJ, Leite CAL, Carvalho CBM. Susceptibilidade a antimicrobianos de bactérias isoladas de otite externa em cães. Arq. Bras. Med. Vet. Zootec 2005; 57:405-408.

5. Banu A, Anand M, Nagi N. White coats as a vehicle for bacterial dissemination. J Clin Diagn Res 2012; 6:1381-1384.

6. Oliveira L, Leite CAL, Brilhante, RSN, Carvalho, CBM. Etiology of canine otitis media and antimicrobial susceptibility of coagulase-positive Staphylococci in Fortaleza city, Brazil. Braz. J. Microbiol 2006; 37: 144-147.

7. Penna B, Varges R, Medeiros L, Martins GM, Martins RR, Lilenbaum W. Species distribution and antimicrobial susceptibility of staphylococci isolated from canine otitis externa. Vet Dermatol 2010; 21: 292-296.

8. Quinn PJ, Carter ME, Markey B, Carter GR. Clinical Veterinary Microbiology. 1st ed. London: Wolfe/Mosby; 1994.

9. Clinical and Laboratory Standards Institute. Performance standards for antimicrobial disk and dilution susceptibility test for bacteria isolated from animals: Approved Standard. 3 th ed. Wayne, PA: Clinical and Laboratory Standards Institute; 2008.

10. Saridomichelakis MN, Farmaki R, Leontides LS, Koutinas AF. Aetiology of canine otitis externa: a retrospective study of 100 cases. Vet Dermatol 2007; 18:341-347.

11. Zur G, Lifshitz B, Bdolah-Abram T. The association between the signalment, common causes of canine otitis externa and pathogens. J Small Anim Pract 2011; 52:254-258.

12. Malayeri HZ, Jamshidi S, Salehi, TZ. Identification and antimicrobial susceptibility patterns of bacteria causing otitis externa in dogs. Vet Res Commun 2010; 34:435-444.

13. Lyskova P, Vydrzalova M, Mazurova J. Identification and antimicrobial susceptibility of bacteria and yeasts isolated from healthy dogs with otitis externa. J Vet Med A Physiol Pathol Clin Med 2007; 54:559-563.

14. Hariharan H, Coles M, Poole D, Lund L, Page R. Update on antimicrobial susceptibilities of bacterial isolates from canine and feline otitis externa. Can Vet J 2006; 47:253-255.

15. Fernandes CPM., Hijano A, Lima CS, Fontoura EG, Schramm RC., Félix SR, Nobre MO. A randomized, double-blind, placebo-controlled study to assess the effect of an aqueous extract of Triticum aestivum on canine outer ear inflammation. Pesq Vet Bras 2017, 37(11):1270-1274.

16. SasakiA, ShimizuA, Kawano, J, Wakita Y, Hayashi T, Ootsuki S. Characterization of Staphylococcus intermedius isolates from diseased and healthy dogs. J Vet Med Sci 2005; 67:103-106.

17. Futagawa-Saito K, Ba-Thein W, Fukuyasu T. High occurrence of multi-antimicrobial resistance in Staphylococcus intermedius isolates from healthy and diseased dogs and domesticated pigeons. Res Vet Sci 2007; 83: 336-339.

18. Rodríguez-Avial C, Álvarez-Novoa A, Losa A, Picazo JJ. Aumento significativo de la colonización por Staphylococcus aureus entre los estudiantes de medicina durante la realización de las prácticas en el hospital. Enferm Infecc Microbiol Clin 2013; 31:516-519. 
19. Dégi J, Imre K, Cãtanã A. Frequence of isolation and antibiotic resistance of staphylococcal flora from external otitis of dogs. Vet Rec 2013; 173:42.

20. Guardabassi L, Schwarz S, Lloyd DH. Pet animals as reservoirs of antimicrobial-resistant bacteria. J Antimicrob Chemother 2004; 54: 321-332.

21. Bhargava K, Zhang Y. Multidrug-resistant coagulase-negative Staphylococci in food animals. J Appl Microbiol 2012; 113:1027-1036.

22. Bugden D. Identification and antibiotic susceptibility of bacterial isolates from dogs with otitis externa in Australia. Aust Vet J 2007; 91: 43-46.

23. Spinosa HC, Górniak SL, Bernardi MM. Farmacologia aplicada à medicina veterinária. 5. ed. Rio de Janeiro: Guanabara Koogan, 2011; p. 361-433.

24. Martino L, Nocera FP, Mallardo K, Nizza S, Masturzo E, Fiorito F, Iovane G, Catalanotti P. An update on microbiological causes of canine otitis externa in Campania Region, Italy. Asian Pac J Trop Biomed 2016; 6:384-389.

25. Morris DO. Medical therapy of otitis externa and otitis media. Vet Clin North Am Small Anim Pract 2004; 34:541-555.

26. Bourély C, Cazeau G, Jarrige N, Leblond A, Madec JY, Haenni M, Gay E. Antimicrobial resistance patterns of bacteria isolated from dogs with otitis. Epidemiol Infect 2019; 147:e121.

27. Mekic S, Matanovic K, Seol B. Antimicrobial susceptibility of Pseudomonas aeruginosa isolates from dogs with otitis externa. Vet Rec 2011; 169(5):125.

28. Jacobson L. Diagnosis and medical treatment of otitis externa in the dog and cat :review article. J S Afr Vet Assoc 2002; 4:162-170.

29. Lloyd DH. Reservoirs of antimicrobial resistance in pet animals. Clin Infect Dis 2007; 45:148-152.

30. Pye C. Pseudomonas otitis externa in dogs. Can Vet J. 2018; 59(11):1231-1234.

31. Pye CC, Yu AA, Weese JS. Evaluation of biofilm production by Pseudomonas aeruginosa from canine ears and the impact of biofilm on antimicrobial susceptibility in vitro. Vet Dermatol 2013; 24: 446-e99.

32. Robinson VH, Paterson S, Bennett C., Steen SI. Biofilm production of Pseudomonas spp. isolates from canine otitis in three different enrichment broths. Vet Dermatol 2019; 30: 218-e67.

33. Pereira IA, Soares LC, Coelho SMO, Pribul, BR, Souza, MMS. Suscetibilidade à azitromicina de isolados bacterianos de processos infecciosos em cães e gatos. Pesq Vet Bras 2009; 29:153-159.

34. Blair JMA, Webber MA, Baylay AJ, Ogbolu DO, Piddock LJV. Molecular mechanisms of antibiotic resistance. Nat Rev Microbiol 2015; 13:42-51.

35. Cunha RC, Rosa MDH, Silva C, Santos FDS, Leite FPL. Staphylococcal slime layers and biofilm from different origins. Cienc Rural 2019; 49(5): e20180783 